\title{
In vivo Comparative Anti-Inflammatory and Analgesic Activities of Root Bark, Stem and Leaf Extracts of Capparis erythrocarpus (Capparaceae)
}

\author{
Emmanuel Kofi Kumatia ${ }^{1, *}$, Stephen Antwi ${ }^{2}$, Henry Brew-Daniels ${ }^{1}$, Alfred Ampomah Appiah', Augustine \\ Ocloo $^{2}$
}

\section{Emmanuel Kofi Kumatia ${ }^{1, *}$, Stephen Antwi ${ }^{2}$, Henry Brew-Daniels' ${ }^{1}$, Alfred Ampomah Appiah', Augustine $\mathrm{Ocloo}^{2}$}

'Department of Phytochemistry, Centre for Plant Medicine Research, Mampong-Akwapim, GHANA. 2Department of Pharmacology, Centre for Plant Medicine Research, Mampong-Akwapim, GHANA.

Correspondence

Dr. Emmanuel Kofi Kumatia

Department of Phytochemistry, Centre for Plant Medicine Research, Mampong-Akwapim, GHANA.

Phone no : + 233342195766

E-mail: kofi2rhyme@yahoo.com

\section{History}

- Submission Date: 30-11-2018;

- Review completed: 03-01-2019;

- Accepted Date: 30-01-2019

DOI : 10.5530/pj.2019.11.82

Article Available online

http://www.phcogj.com/v11/i3

\section{Copyright}

(C) 2019 Pharmacognosy Journal. This is an open-access article distributed under the terms of the Creative Commons Attribution 4.0 International license.

\begin{abstract}
Introduction: The root bark powder of the medicinal plant Capparis erythrocarpus is used at the Centre for Plant Medicine Research (In Ghana) against inflammatory pain disorders. The whole plant is destroyed to obtain the root bark which constitutes only $11.1 \%$ of the plant. Hence, the plant is going extinct. We therefore sought to evaluate anti-inflammatory and analgesic activities of the root bark, stem and leaf of $C$. erythrocarpus in order to explore them as substitute(s) anti-inflammatory and analgesic agent to the root bark. Methods: Carrageenan induced paw oedema assay was used to evaluate anti-inflammatory activity. Hot plate and acetic acid induced writhing assays were employed to ascertain analgesic activity. Results: The extracts of the root bark (CRB) and leaf $(C L)$ produced significant $(p<0.05)$ antiinflammatory activity of 48.93 and $37.42 \%$ at 50 and $200 \mathrm{mg} / \mathrm{kg}$ p.o. respectively whereas the stem extract (CS) was inactive. Moreover, the extracts produced significant $(p<0.05)$ analgesic activity. The analgesic activity $(178.20-248.70 \%)$ of the extracts were higher than that of morphine (136.70\%) at $5 \mathrm{mg} / \mathrm{kg}$ i.m. in the hot plate assay. CS (200 mg/kg p.o.) produced the highest analgesic activity $(54.61 \%)$ among the extracts and diclofenac sodium $(41.15 \%)$ at $5 \mathrm{mg} / \mathrm{kg}$ p.o. in the writhing assay. Conclusion: These results indicates that the leaf of $C$. erythrocarpus can be substituted for the root as analgesic and anti-inflammatory agent. Whiles, the stem can also be used as analgesic agent. This will save the plant from extinction.
\end{abstract}

Key words: Pain, Phytochemical constituents, Hot plate, Writhing assay, Oedema.

\section{INTRODUCTION}

Capparis erythrocarpus is a shrub that belongs to the Capparaceae family of flowering plants. The plant is mostly scandent with $3-14 \mathrm{~cm}$ long and $1.5-5.0 \mathrm{~cm}$ broad leaves of different shapes that ranges from abovate through elliptic to ovate and lanceolate. Furthermore, the leaf has cuneate to rounded base and sharply acuminate to obtuse apex. ${ }^{1}$ The plant produces $5.0 \mathrm{~cm}$ long scarlet fruits from flowers which sprouts as cluster of stout pedicels at the end of young branches. ${ }^{1}$ The stem is full of sharp long thorns. The leaf is also full of clusters of tiny thorns.

The root of C. erythrocarpus is used in traditional medicine to treat rheumatoid arthritis, blurred vision, partial male impotence, urinogenital pain, otitis, ear pain and gas in the stomach. ${ }^{1,2}$ The powdered root bark of C. erythrocarpus (Known as Serapac) is an oral herbal medication dispense at the Centre for Plant Medicine research at Mampong - Akwapim, Ghana for treatment of arthritis, pain and inflammatory disorders. Chronic toxicity studies, anti-arthritic and anti-nociceptive activities of the root bark of
C. erythrocarpus have been evaluated..$^{3-5}$ However, there has not been any scientific investigation of the medicinal properties of the stem and leaf of the plant. Furthermore, the whole plant is destroyed to obtain the root bark. This is causing extinction of the plant. This research therefore, seeks to evaluate the anti-inflammatory and analgesic activities of the root bark, stem and leaf of C. erythrocarpus in order to explore the stem and leaf as an alternate antiinflammatory and/or analgesic agent to the root and hence, save the plant from extinction.

\section{MATERIALS AND METHODS}

Identification, Collection and Processing of Plant Materials

Five plants were uprooted at Dodowa in the Greater Accra Region of Ghana in January, 2017. The plant was identified by Mr. H. R. Blagoggee, a botanist at Centre for Plant Medicine Research (CPMR), Ghana. The root, stem and leaf were given voucher specimen number 4880, 4881 and 4883 and stored

Cite this article: Kumatia EK, Antwi S, Brew-Daniels H, Appiah AA, Ocloo A. In vivo Comparative Anti-Inflammatory and Analgesic Activities of Root Bark, Stem and Leaf Extracts of Capparis erythrocarpus (Capparaceae). Pharmacog J. 2019;11(3):515-20. 
in the herbarium of CPMR. The root was cut off and washed with portable water. The root bark was removed and chopped into pieces. The leaves were also removed from the branches. The stem was also chopped into pieces. The plant materials were then sun dried for 8 days and their weights determined separately.

\section{Extraction}

The plant materials were separately pulverized and stored in air tight plastic bags. The pulverized root bark $(1.0 \mathrm{~kg})$ was extracted with $70 \%$ ethanol $(5 \mathrm{~L} \mathrm{x} 2)$ for 5 days. The extracts were combined filtered and concentrated with rotary evaporator at $45^{\circ} \mathrm{C}$. The aqueous extract obtained was lyophilized to obtain a brownish gummy solid which was coded CRB. The stem and leaf (1.0 kg each) were also taken through similar procedure to obtain brownish gummy solid and dark green solid which were coded CS and CL respectively and stored in air tight glass containers. The yields of the extracts were calculated.

\section{Phytochemical Screening of the Extracts}

The extracts $(30 \mathrm{ml}$ each) were taken and screened for the presence or absence of ten (10) groups of phytochemical compounds according to Trease and Evans. ${ }^{6}$ They were: alkaloids, flavonoids, triterpenes, saponins, free reducing sugars, phenolic compounds, polyuronoids, cyanogenic glycosides, athracenosides and phytosterols.

\section{Animals}

Rats and mice were obtained from the Animal House Unit of CPMR and housed in aluminum cages under standard temperature and pressure with free access to sterile water and feed ad libitum. Mice used in the acetic acid-induced assays were fasted overnight just before the experiment. Guidelines and procedures provided by Foundation for Biomedical Research on the use of animals in research was applied in caring for the animals and handling them.?

\section{Drugs and chemicals}

Carrageenan and Acetic acid were procured from Sigma Chemical Co. (St. Louis, USA). Diclofenac sodium salt powder was purchased from Sigma-Aldrich (St. Louis, USA). Morphine sulphate injection (i.v.) was purchase from Laboratories STEROP (Brussels). Normal saline was purchased from Otsuka Pharmaceuticals India Private Limited (VasanaChakawadi, India).

\section{Anti-Inflammatory Activity Assay}

Anti-inflammatory activity of the extracts was evaluated using carrageenan induced paw oedema model in rats. ${ }^{8,9}$ Male Sprague-Dawley rats $(185-200 \mathrm{~g})$ were divided into 11 groups $(n=5)$. Group 1- 3 were given CRB 5 - $200 \mathrm{mg} / \mathrm{kg}$ p.o. Group 4 - 6 were also given CL 5 - $200 \mathrm{mg} / \mathrm{kg}$ p.o. Furthermore, Group 7 - 9 were also given CS 5 - 200 mg/kg p.o. Group 10-11 were given $2 \mathrm{mg} / \mathrm{kg}$ p.o. of diclofenac sodium as standard drug or $1 \mathrm{ml}$ each of distilled water as vehicle control respectively. Prior to drug/ extract administration, oedema was induced by the sub-plantar injection of $0.1 \mathrm{ml}$ Carrageenan in normal saline $(1 \% \mathrm{w} / \mathrm{v})$ in the right hind paw of each animal. The paw volume of the right hind limb of each animal was measured prior to induction of oedema (Vo) and hourly (Vt) until the $4^{\text {th }}$ hr post drug/extract administration using plethysmometer. (Vt - Vo) which represent change in paw volume is taken as oedema. Anti-inflammatory activity (AI) was calculated using the formula:

$$
A I=\frac{\left(\left(\text { Mean }\left(V_{t}-V_{o}\right) c-\left(\text { Mean }\left(V_{t}-V_{o}\right) t\right)\right.\right.}{\left(\text { Mean }\left(V_{t}-V_{o}\right) c\right.} \times 100 \%
$$

Where: Mean (Vt-Vo)c and Mean (Vt-Vo)t represents mean oedema of the control and treated groups respectively over the duration of the experiment.

\section{Analgesic Activity Assays}

Hot Plate Assay

The mouse hot plate test used to evaluate the analgesic activity of the extracts was performed according to Eddy and Leimbach. ${ }^{9,10}$ Briefly, C57/BL6 mice (15-25 g) of either sex were divided into 8 Groups $(n=4)$. Each mouse was placed on an electric hot plate (UGO Basile hot/cold plate 35100$)$ maintained at $55 \pm 0.5^{\circ} \mathrm{C}$. The time taken for a mouse to lick, lift, shake or stamp any of the hind limbs or jump constitutes latency time, recorded as analgesic response. Baseline latencies (To) were calculated as averages of two measurements before any treatment of mice. Average baseline latency of mice used for this test ranged from $3.3-8.0$ s. Extracts were administered as follows. Group 1-3 were given CR 5 - $200 \mathrm{mg} / \mathrm{kg}$ p.o. Group 4 - 6 also received CL 5-200 mg/kg p.o., whereas Group 7 - 8 received Morphine sulphate $5 \mathrm{mg} / \mathrm{kg}$ i.m. as standard drug or $0.2 \mathrm{ml}$ each of distilled water as vehicle control respectively. Latency of each mouse was then obtained hourly (Tt) for $5 \mathrm{~h}$ after each treatment. Analgesic activity was calculated as the sum of percentage Maximal probable effect (\% MPE) over the experimental period. \% MPE was calculated as: ${ }^{11}$

$$
\% \mathrm{MPE}=((\mathrm{Tt}-\mathrm{Tt}) / \mathrm{To}) \times 100
$$

The analgesic activity in the hot plate assay was calculated as overall analgesic activity for each group in the hot plate test which was obtained as mean $\% \mathrm{MPE} \pm$ S.E.M.

\section{Acetic Acid Induced Writhing Assay}

Analgesic activity of the extracts was also evaluated in the acetic acid induced-writhing model. ${ }^{12}$ Female Swiss albino mice (21-29 g) were divided into 8 groups $(n=4)$. Group $1-3$ were given CR 5 - $200 \mathrm{mg} / \mathrm{kg}$ p.o. Group $4-6$ were also given CR $5-200 \mathrm{mg} / \mathrm{kg}$ p.o. Finally, Group 7 and 8 received diclofenac sodium, $10 \mathrm{mg} / \mathrm{kg}$ p.o. as standard drug and $0.2 \mathrm{ml}$ of distilled water as vehicle control respectively. Thereafter, each mouse was administered $1 \mathrm{ml} / 100 \mathrm{~g}$ (i.p.) of $1 \% \mathrm{v} / \mathrm{v}$ aqueous acetic acid $45 \mathrm{~min}$ after treatment and isolated into transparent Perspex cage. Writhing movements and stomach contortions produced by each mouse after induction was counted for $20 \mathrm{~min}$. Percentage analgesic activity (\%AE) of the extracts was calculated by comparing the average writhing movements of the vehicle control group and drug treated group which is given by the formula:

$$
\% \mathrm{AE}=((\mathrm{MRc}-\mathrm{MRt}) / \mathrm{MRc}) \times 100
$$

Where: $\mathrm{MRc}=$ Average writhing count of the vehicle treated control group; $\mathrm{MRt}=$ Average writhing count of treated group.

\section{Statistical Analysis}

Graphpad Prism 5 was used for all statistical analysis. Each point on the time course curve or column in the bar chart represents mean \pm S.E.M. Data obtained for the time course curves were analysed using Two Way ANOVA followed by Bonferroni's Post hoc test to determine statistical significant. Whereas, One-way ANOVA was employed to analyse data for the bar charts followed by Dunnett's Post hoc test for statistical significant. Results were considered to be statistically significant when $p<0.05$ by comparing the test subjects to the control group.

\section{RESULTS AND DISCUSSION}

\section{Percentage Composition of Morphological Parts of $C$. erythrocarpus and Yield on Extraction}

Table 1 shows the composition of the various part of the plant and their percentage yield upon extraction. The stem formed the highest percentage of the plant (55.6\%). The root bark constitutes only $11.1 \%$ of the plant. Hence discarding the stem and leaf of the plant means $66.7 \%$ of the plant is being wasted. 
Table 1: Percentage Composition of the Various Part of $C$. erythrocarpus and Yield on Extraction.

\begin{tabular}{ccccc}
\hline Plant part & $\begin{array}{c}\text { Weight per } \\
\text { plant }(\mathrm{kg})\end{array}$ & $\begin{array}{c}\text { Composition } \\
\text { per plant }(\%)\end{array}$ & \multicolumn{2}{c}{ Yield on extraction } \\
\cline { 5 - 6 } & 0.4 & 11.1 & 144.50 & $(\% \mathrm{w} / \mathrm{w})$ \\
\hline Root bark & 0.4 & 16.7 & - & - \\
Wood in the root & 0.6 & 55.6 & 80.81 & 8.0 \\
Stem & 2.0 & 16.7 & 46.64 & 4.6 \\
Leaf & 0.6 & & & \\
\hline
\end{tabular}

Not extracted $=-$

\section{Anti-Inflammatory Activity}

Figure $1 \mathrm{~A}, \mathrm{C}$ and $\mathrm{E}$ shows the effects of ethanol extracts of the root bark (CRB), stem (CS) and leaf (CL) of C. erythrocarpus on inflammatory response in Sprague-Dawley rats on time course curve. Whereas, B, D and $\mathrm{F}$ represents the mean oedema of extracts, Diclofenac sodium (DS) and control treated groups respectively. From the results DS ( $2 \mathrm{mg} / \mathrm{kg}$ p.o.) and CRB 5-200 mg/kg p.o. suppressed the development of inflammation caused by carrageenan injection. The effect of the extract was doseindependent (Figure $1 \mathrm{~A}$ and $\mathrm{B}$ ).

Moreover, the results also show that CS has no inhibitory effect on the development of inflammation caused by carrageenan injection relative to the negative control (Figure $1 \mathrm{C}$ and D). This indicates that CS was inactive as an anti-inflammatory agent.

Furthermore, CL dose - dependently suppressed the development of inflammation caused by carrageenan injection. The observed effect was however not comparable to the positive control (Diclofenac). Also, the inhibitory effect of the root bark extract (Figure $1 \mathrm{~A}$ and $\mathrm{B}$ ) appears more pronounced than that of the leaves extract (Figure $1 \mathrm{E}$ and $\mathrm{F}$ ). The antiinflammatory activity of CRB 5-200 $\mathrm{mg} / \mathrm{kg}$ p.o. was calculated to be $44.81,46.35,48.93 \%$ respectively. And that of CL 5-200 mg/kg p.o. were $1.06,16.32$ and $37.42 \%$ for the respective doses.

Carrageenan-induced oedema in rat paws is an established assay which involves triphasic progressive release of pro-inflammatory mediators. ${ }^{8,12}$ The first Phase which occurs from 0-1.5 h after carrageenan injection comprises the production of histamine and serotonin. The second phase which occurs from $1.5-2.5 \mathrm{~h}$ is mediated by release of bradykinin. ${ }^{13}$ The last phase is controlled by production of prostaglandins from 2.5-6 $\mathrm{h}$ after induction. ${ }^{14} \mathrm{CRB}$ and CL produced significant $(p<0.05)$ inhibition of inflammation from 3-4h period which corresponds to the third Phase on the time course curve in this assay (Figure $1 \mathrm{~A}$ and $\mathrm{E}$ ). This indicates that CRB and CL produce anti-inflammatory activity by suppressing the synthesis or action of prostaglandins. Although, CRB, CL and DS produced pronounced anti-inflammatory activity in this assay, their overall anti-inflammatory activities calculated as inhibition of mean oedema formation. insignificant $(p>0.05)$ (Figure $1 \mathrm{~B}$ and F). This may be due to the low doses of the extracts and drug used or the short duration in which the experiment was performed (1-4h) instead of (1-6 h).

\section{Analgesic Activity} Hot Plate Assay

The results of the analgesic activity of CRB, CS and CL are shown in Figure $2 \mathrm{G}, \mathrm{I}$ and $\mathrm{K}$ on time course curves. H, J and L represents the mean analgesic activities of the extracts over the duration of the experiment. All the three extracts produced very significant $(p<0.05)$ analgesic activity in the hot plate assay. The analgesic activity of CRB appears to be dose-depended between $5-50 \mathrm{mg} / \mathrm{kg}$ p.o. and levels off at a certain dose between 50 - $200 \mathrm{mg}$ where increasing the dose of the extract does not result in the corresponding increase in activity (Figure $2 \mathrm{H}$ ). The

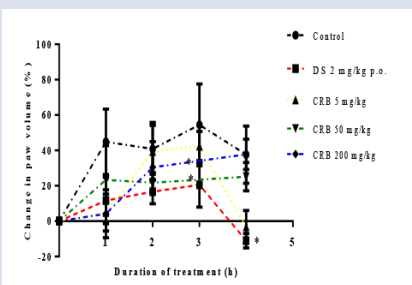

A

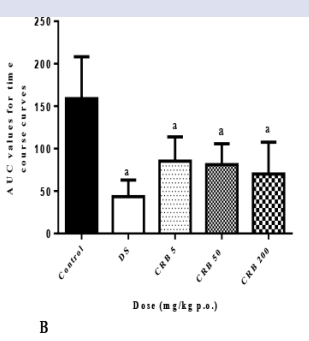

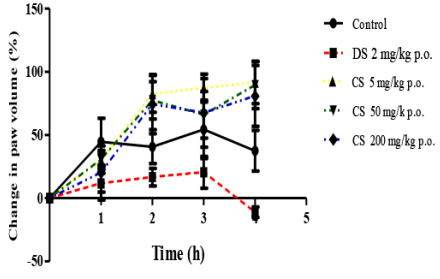

C

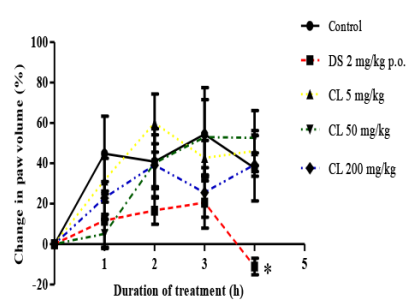

E

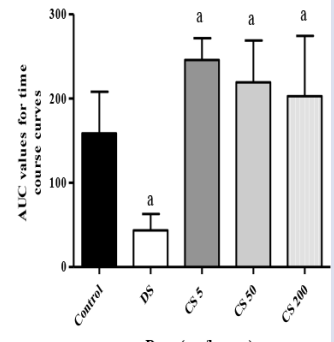

Dose (mg kg p.o.)

D

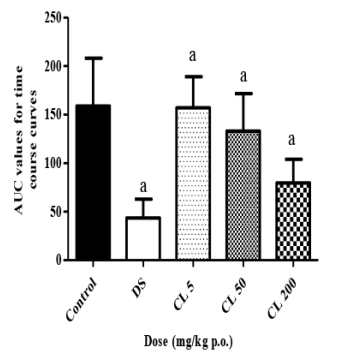

F
Figure 1: Effect of CR (5 - $200 \mathrm{mg} / \mathrm{kg}$ p.o.), CL (5 - $200 \mathrm{mg} / \mathrm{kg}$ p.o.) and diclofenac sodium ( $2 \mathrm{mg} / \mathrm{kg}$ p.o.) on inhibition of carrageenaninduced paw oedema in rat's paw on time course curve ( $A$ and $C$ ) and total area under the curve ( $B$ and $D)$. Each point or column represents mean $\pm \operatorname{SEM}(n=5) .{ }^{*} p<0.05$ compared to vehicle treated control group (Two-way ANOVA followed by Bonferroni's post hoc test). ${ }^{a} p>0.05$ compared to vehicle treated control group (One-way ANOVA followed by Dunnett's post hoc test).

analgesic activity of CS also followed the same trend as that of CRB in the hot plate assay (Figure $2 \mathrm{~J}$ ). On the other hand, CL appears to produce inverse dose depended analgesia. The $50 \mathrm{mg} / \mathrm{kg}$ p.o. dose of CRB and CS produced the highest analgesic activities of 248.7 and $178.2 \%$ respectively. Whereas, CL $5 \mathrm{mg} / \mathrm{kg}$ p.o produced the highest analgesic activity of $184.5 \%$. CRB demonstrated the highest analgesic activity among the extracts in the hot plate assay. The analgesic activity of the standard drug, Morphine sulphate (MS $5 \mathrm{mg} / \mathrm{kg}$ i.m.), was calculated to be $136.70 \%$. The extracts at $50-200 \mathrm{mg} / \mathrm{kg}$ p.o. showed higher analgesic activity than MS but at $5 \mathrm{mg} / \mathrm{kg}$ p.o. only the leaf showed higher activity than MS (Figure $2 \mathrm{H}$, J and L).

The hot plate assay is used to evaluate the analgesic activity of drugs which elicit analgesia through the central nervous system. ${ }^{15}$ Since CRB, CS and CL showed tremendous analgesia in the hot plate assay, it indi- 


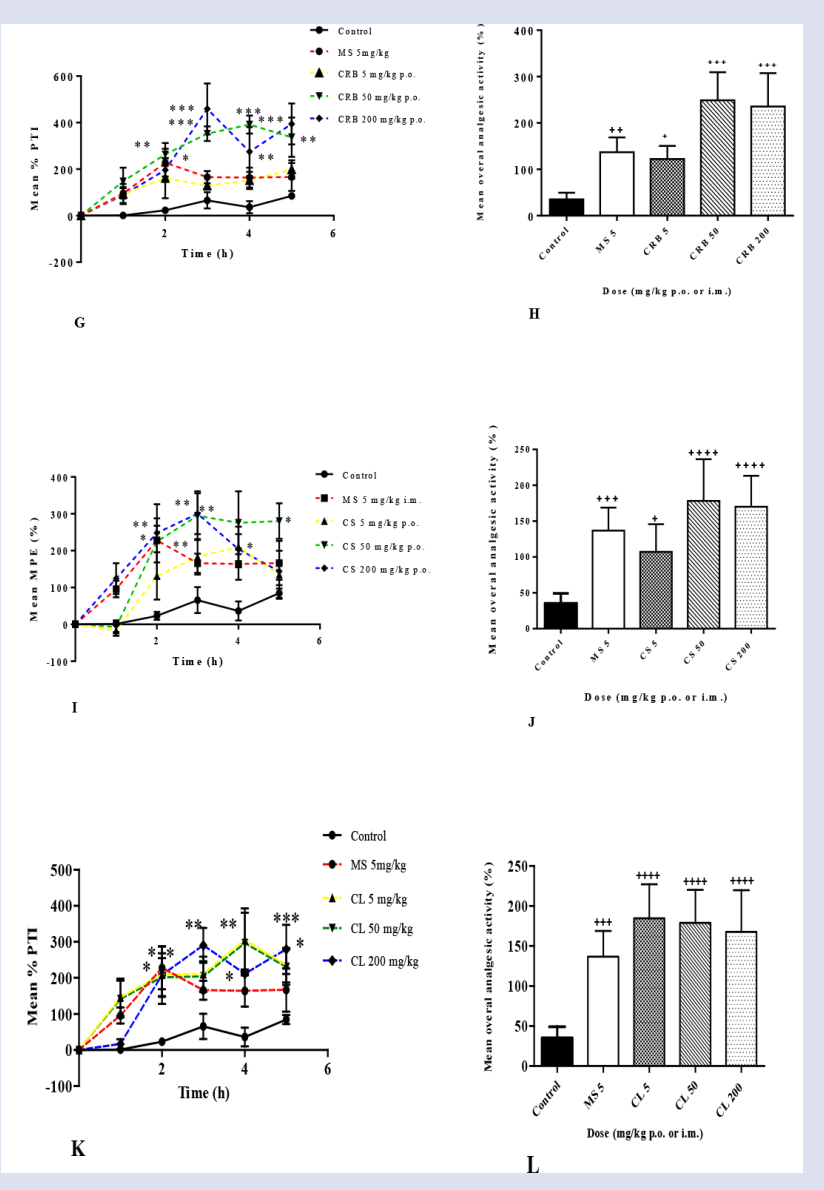

Figure 2: Effect of CRB, CS or $\mathrm{CL}(5-200 \mathrm{mg} / \mathrm{kg}$ p.o.) and $\mathrm{MS}$, ( $5 \mathrm{mg} / \mathrm{kg}$ i.m.) on prolongation of latency of mice to react to pain on time course curve ( $\mathrm{G}, \mathrm{I}$ and $\mathrm{K}$ ) and mean overall analgesic activity $(\mathrm{H}, \mathrm{J}$ and $\mathrm{L})$ in hot plate assay. Each point or column represents mean $\pm \operatorname{SEM}(n=4) .{ }^{*} p<0.05,{ }^{* *} p<0.01$ and ${ }^{* * *} p<0.001$ compared to the control group (Two-way ANOVA followed by Bonferoni's post hoc test). ${ }^{+} p<0.05,{ }^{++} p<0.01,{ }^{++} p<0.001$ and ${ }^{++++} p<0.0001$ compared to the control group. (One-way ANOVA followed by Dunnett's post hoc test).

cates that the $70 \%$ ethanol extract C. erythrocarpus root bark, stem and leaf may possess central analgesic effect.

\section{Writhing assay}

Figure $3 \mathrm{M}, \mathrm{N}$ and $\mathrm{O}$. All the extracts (CRB, CS and CL) showed dose dependent analgesic activity in the acetic acid-induced writhing assay. The highest dose of CRB $(200 \mathrm{mg} / \mathrm{kg}$ p.o. $)$ produced $(p<0.05)$ analgesic activity of $17.45 \%$. CS at (200 mg/kg p.o.) also produced significant $(p<0.01)$ analgesic activity of $54.61 \%$ (Figure 3$)$. The highest dose of CL (200 mg/kg p.o.) also produced the highest analgesic response of $27.43 \%$. The analgesic activity of the standard drug, diclofenac sodium, was calculated to be $41.15 \%$.

The acetic acid-induced writhing assay is used to evaluate both central and peripheral analgesic activities of substances. ${ }^{15}$ Intraperitoneal injection of acetic acid into rats or mice abdominal cavity results in elevated levels of prostaglandins in the peritoneal exudates after about 30 min. ${ }^{16}$ The stretching and abdominal contortions obtained in the writhing test therefore correlates with sensitization of nociceptors to the production of prostaglandins. ${ }^{15} \mathrm{CRB}$ and $\mathrm{CL}$ significantly suppressed writhing

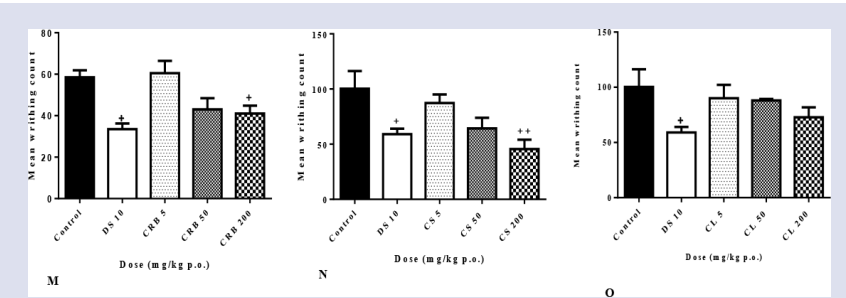

Figure 3: Effect of CRB, CS or CL (5 - $200 \mathrm{mg} / \mathrm{kg}$ p.o.) and diclofenac sodium (10 mg/kg p.o.) on inhibition of acetic acid-induced writhing movements in mice ( $\mathrm{M}, \mathrm{N}$ and $\mathrm{O})$. Each column represents mean $\pm \operatorname{SEM}(n=5) .{ }^{+} p<0.05,{ }^{++} p<0.01$ compared to vehicle treated control group (One-way ANOVA followed by Dunnett's post hoc test).

numbers in the mouse writhing assay. Hence, the analgesic activity of $\mathrm{CRB}$ and CL extracts may be due to their ability to suppress the cyclooxygenase enzyme and decrease the biosynthesis of prostaglandins. The result obtained for $\mathrm{CRB}$ and $\mathrm{CL}$ correlated with the results obtained for them in the carrageenan-induced oedema assay. Thus, CRB and CL may also possess peripheral analgesic property in addition to the central analgesic property. These results also indicate that the anti-inflammatory constituents of $\mathrm{CRB}$ and $\mathrm{CL}$ are also responsible for their analgesic activity in the acetic acid-induced writhing assay. CS on the other hand, demonstrated strong analgesic activity in both hot plate and acetic acid induced writhing assays but did not show any anti-inflammatory activity in the carrageenan induced oedema assay. This indicates that CS may possess only central analgesic property without peripheral analgesic property.

Previous reports indicated that C. erythrocarpus root possessed central analgesic property probably mediated by adenosinergic receptors in the formalin assay. ${ }^{5}$ However, this is first report on the analgesic and antiinflammatory activities of stem and leaf extracts of C. erythrocarpus.

\section{Phytochemical screening of C. erythrocarpus}

The root bark of the plant contains the highest number (Five) of phytochemical constituents whiles the stem and the leaf contains equal numbers (Four each). Reducing sugar, triterpenes and phytosterols were presents in all the three extracts. In addition, saponins were present in the root bark and leaf but absent in the stem. Alkaloids were also present in the root bark and stem extracts but not in the leaf.

Finally, some classes of phytochemical constituents such as saponins, triterpenes, phytosterols and alkaloids are known to possess anti-inflammatory and analgesic properties. The presence of these constituents in the root bark, stem and leaf of C. erythrocarpus contributes to the antiinflammatory and / or analgesic effects of the plant extracts.

\section{CONCLUSION}

This study showed that, the $70 \%$ ethanol leaf extract of C. erythrocarpus (CL) possessed anti-inflammatory and analgesic properties similar to that of the $70 \%$ ethanol extract of the root bark (CRB). CL may therefore, be substituted in place of CRB to treat inflammatory pain in order to prevent the plant from going extinct. However, the $70 \%$ ethanol extract of the stem (CS) of the plant did not show anti-inflammatory activity. CS also appears to possess only central analgesic properties. Hence, CS can be used to treat other forms of pain, but not inflammatory pain.

This is the first work that reports on the anti-inflammatory and analgesic activity of C. erythrocarpus stem and leaf. The anti-nociceptive activity of the root of this plant had already been established. 


\section{ACKNOWLEDGEMENT}

The authors wish to thank the technicians at the Animal House Unit of the Pharmacology Department of CPMR, Mampong-Akwapim. Ghana, for their technical support.

\section{CONFLICT OF INTEREST}

The authors declare that there are no conflicts of interest.

\section{ABBREVIATIONS}

ANOVA: Analysis of variance; CRB: C. erythrocarpus root bark extract; CS: C. erythrocarpus; CL: C. erythrocarpus leaf; CPMR: Centre for Plant Medicine Research; DS: Diclofenac sodium; i.m; Intramuscular; i.v.: Intravenous; AUC: Area under the curve; MPE: Maximum probable effect; T: Latency; t: Time; MRc: Mean Writhing count of control group; MRt: Mean writhing count of treated group; SEM: Standard error of the mean.

\section{REFERENCES}

1. Mshana NR, Abbiw DK, Addae-Mensah I, Adjanouhoun E, Ahyi MRA, Ekpere $\mathrm{JA}$, et al. Traditional Medicine and Pharmacopoiea: Contribution to the Revision of Ethnobotanical and Floristic Studies in Ghana. Organisation of Africa Unity/ Scientific, Technical and Research Commission (OAU/STRC). 2000

2. Abbiw DK. Useful plants of Ghana. $1^{\text {st }}$ ed. Intermediate Technology Publications and Royal Botanic Gardens. London, Kew. 1990.

3. Martey ONK, Armah GE, Sittie AA, Okine LKN. Chronic toxicity study of ground root bark of Capparis erythrocarpus (Cappareceae) in male Sprague-dawley rats. Pakistan J Biol Sci. 2013;16(23):1706-13.
4. Danquah CA, Woode E, Boakye-Gyasi E. Anti-arthritic effects of an ethanolic extract of Capparis erythrocappus Isert roots in Freund's adjuvant-induced arthritis in rats. J Pharmacol Toxicol. 2011;6(3):201-17.

5. Woode E, Danquah CA, Boakye-Gyasi E, Ansah C, Ainooson G. Antinociceptive effects of an ethanolic extract of Capparis erythrocappus Isert roots in the mice formalin test. Int J Pharmacol. 2009;5(6):354-61.

6. Trease E, Evans WC. Textbook of Pharmacognosy. 13 $3^{\text {th }}$ ed. London: Billiare Tindall. 1989;200-1.

7. Foundation for Biomedical Research (FBR). The biomedical investigator's handbook for researchers using animal models. $1^{\text {st }}$ ed. Washington, DC. 1987.

8. Winter CA, Risley EA, Nuss GW. Carrageenan induced edema in hind paw of the rat as an assay for anti-inflammatory drugs. Proc Soc Exp Biol Med. 1962;111(3):544-7.

9. Kumatia EK, Annan K, Dickson RA, Mensah AY, Aponsah IK, Appiah AA, et al. Anti-inflammatory and analgesic effects in rodent models of ethanol extract of Clausena anisata roots and their chemical constituents. Natur Produc Commu. 2016;11:1-6.

10. Eddy NB, Leimbach D. Synthetic analgesics II. Dithienylbutenyl and dithienylbutylamines. J Pharmacol Exp Ther. 1953;107(3):385-93.

11. Wen Q, Yu G, Li Y, Yan L, Gong Z. Pharmacological mechanisms underlying the anti-nociceptive and tolerance effects of the 6,14-bridged oripavine compound 030418. Acta Pharmacolo Sin. 2011;32(10):1215-24.

12. Koster R, Anderson M, DeBeer J. Acetic acid for analgesic screening. Fed Proceds. 1959;18:412-7.

13. DiRosa M. Studies of acute inflammatory response induced in rats in different sites by carrageenan. J Pharm Pharmacol. 1972;24(2):89-102.

14. Spector WG. The inflammation response. J Pathol Bact. 1960;84:391-403.

15. Yong Y, Ya G, Yue-Ting L. Anti-inflammatory and analgesic activities of a novel biflavonoid from shells of Camellia oleifera. Int J Molecul Sci. 2012;13(10):12401-11.

16. Derardt R, Jougney S, Delevalcee F, Falhout M. Release of prostaglandins E and $\mathrm{F}$ in an algogenic reaction and its inhibition. Eur J Pharmacol. 1980;61(1):17-24.

\section{GRAPHICAL ABSTRACT}

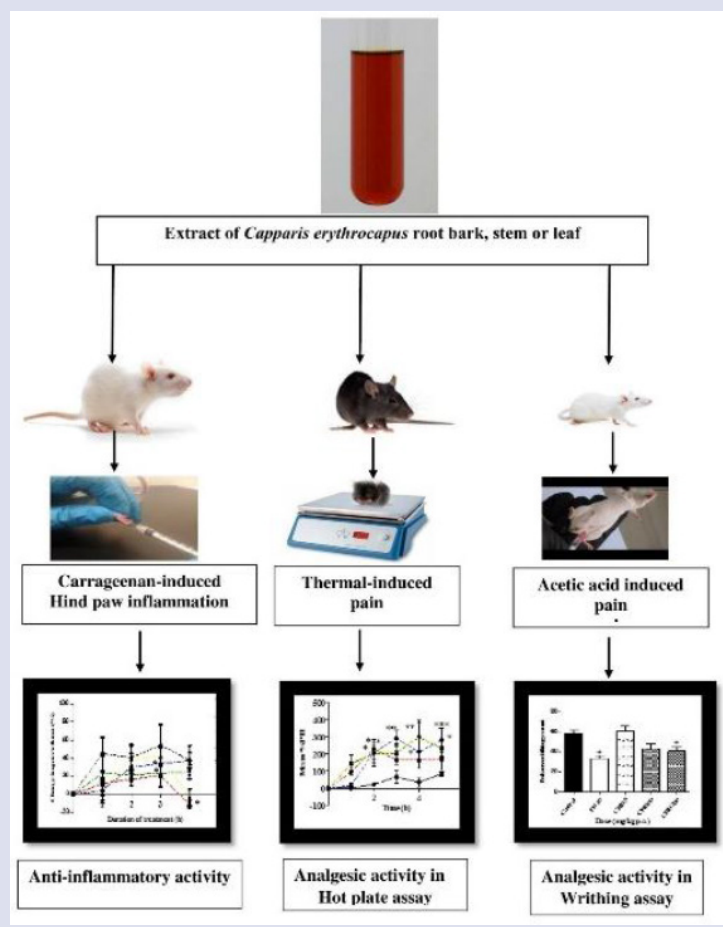

\section{SUMMARY}

- Problem Statement and Hypothesis: C. erythrocarpus, an important medicinal plant whose root is used to prepare an herbal medicine that is employed to treat arthritis and other inflammatory pain conditions, is now difficult to obtain in Ghana, because of the indiscriminate destruction of the plant to obtain the root. The present study was conducted to ascertain and compare the antiinflammatory and analgesic activity of the leaf, stem and root back of C. erythrocarpus so as to substitute the leaf and / or stem for the root bark in other to save the plant from extinction.

- Implication of the Results: This study demonstrated that the leaf of C. erythrocarpus can be substituted for the root bark as an anti-inflammatory and analgesic agent whiles the stem can only be used as analgesic agent. This will save the plant from extinction.

- Way Forward: Work is underway to isolate the constituents of the plant, characterize and assay them for their analgesic and anti-inflammatory activities.

\section{ABOUT AUTHORS}

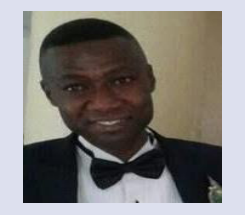

Dr. Emmanuel Kofi Kumatia holds a Ph.D. in Pharmacognosy. He is the Head of the Phytochemistry Department of the Centre for Plant Medicine Research. He has authored and coauthored research articles which were published in peer reviewed scientific journals in the fields of phytochemistry and pharmacognosy. His research areas of interest include isolation and structure elucidation of active principles from plants, inflammation, pain, diabetes, malaria, hypertension and microbiology. 


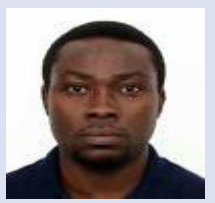

Mr. Stephen Antwi holds an MPhil. in Pharmacology. He is the Head of the Animal Experimentation Unit of the Centre for Plant Medicine Research. He has authored and co-authored research articles which were published in peer reviewed scientific journals in the fields of efficacy, toxicology and mechanism of action of herbal extracts/ medicines.

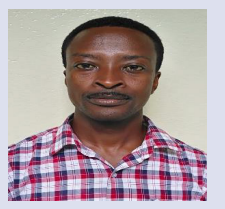

Mr. Henry Brew-Daniels holds an MPhil. in Chemistry. He was the Acting Head of the Phytochemistry Department of the Centre for Plant Medicine Research. He has co-authored research articles which were published in peer reviewed scientific journals. His research areas include heavy metals analysis, pesticide residue analysis and phytochemistry.

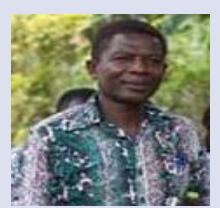

Dr. Alfred Ampomah Appiah is a Pharmacist and holds a Ph.D. in Chemistry. He is a Principal Research Officer and the Deputy Executive Director of the Centre for Plant Medicine Research. He has authored and co-authored many research articles which were published in peer reviewed scientific journals in the fields phytochemistry, pharmacognosy and others. His research areas of interest include isolation and structure elucidation of active principles from plants, prostrate enlargement, Parkinson disease and noncommunicable diseases.

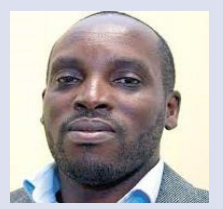

Prof. Augustine Ocloo holds a Ph.D. in Cell and Molecular Biology. He is the Executive Director of the Centre for Plant Medicine Research and a former Head of the Department of Biochemistry at University of Ghana. He has authored and co-authored many research articles which were published in peer reviewed scientific journals in the fields of cell and molecular biology, biochemistry of medicinal plant extracts and others. His research areas of interest include mitochondria as a target for drug discovery, biochemistry and pharmacology of medicinal plant extracts.

Cite this article: Kumatia EK, Antwi S, Brew-Daniels H, Appiah AA, Ocloo A. In vivo Comparative Anti-Inflammatory and Analgesic Activities of Root Bark, Stem and Leaf Extracts of Capparis erythrocarpus (Capparaceae). Pharmacog J. 2019;11(3):515-20. 